\title{
Suomen sijamuotojen nimitykset: kuinka käsiteanalyysi ja tuote- kehittely 1800-luvun kieliopeissa saataisiin hyödyttämään S2- ja äidinkielen opetusta?
}

\author{
MARIA KOK \\ Itä-Suomen yliopisto
}

Tiivistelmä. Artikkeli on oppihistoriallinen katsaus suomen sijamuotojen nimitysten kehityksestä ja erityisesti paikallissijojen nimitysjärjestelmän muotoutumisesta nykyiseen asuunsa. Tutkimusaineistona on käytetty sijamuotojärjestelmän kuvauksia 1800luvun kieliopeissa, erityisesti Gustaf Renvallin teoksessa "Finsk Språklära, Enligt den rena Vest-Finska, i Bokspråk vanliga Dialecten". Suomen paikallissijojen nykyistä nimitysjärjestelmää voidaan suurelta osin pitää Renvallin kehittämänä terminologisena tuotteena, jonka perusteita ja kehittelyprosessia hän myös teoksessaan seikkaperäisesti esittelee. Vaikka Renvallin luomat nimitykset (inessiv, elativ, illativ, adessiv, ablativ, allativ) ovat sisällöllisesti oikeat ja perustuvat hyvään käsiteanalyysiin, ne ovat kuitenkin osoittautuneet ongelmallisiksi. Erityisesti perusasteen äidinkielenopetuksessa ja S2-opetuksessa nämä latinaan pohjautuvat termit ovat työläitä muistaa ja jäävät helposti vieraiksi käyttäjilleen. Lisäksi Renvallin termistö on syrjäyttänyt tieltään aikaisempia kuvausmalleja, joissa olisi ollut ainesta jatkokehittelyyn. Vaikka Renvallin termijärjestelmästä ei ole syytä luopua, vaihtoehtoja sille tarvittaisiin. Hyvän lähtökohdan vaihtoehtoisille tai rinnakkaisille nimityksille voisivat tarjota Reinhold von Beckerin käyttämät 
termit, jotka ovat aiheettomasti jääneet unohduksiin. Myös August Ahlqvistin deskriptiivisiä nimityksiä (sisäinen/ulkoinen olosija, erosija ja tulosija) kannattaisi hyödyntää aktiivisemmin opetuksessa. Lisää aineksia vaihtoehtoisille termeille tarjoaa myös Kalevi Wiikin tutkimus suomen sijamuotojen nimityksistä.

Avainsanat: historialliset kieliopit; kielioppitermistö; sijojen nimitykset; sisäpaikallissijat; ulkopaikallissijat; S2-opetus; suomi äidinkielenä -opetus

\section{Johdanto}

Tarkastelen artikkelissani suomen sijamuotojen nimityksiä ja niiden kehitystä nykyiseen asuunsa 1800-luvun suomen kielen kuvauksissa. Tarkastelun keskiössä on erityisesti paikallissijojen nimitysjärjestelmän muotoutuminen sekä Gustaf Renvallin (1840) teos "Finsk Språklära Enligt den rena Vest-Finska, i Bokspråk vanliga Dialecten", jota ilman suomen paikallissijoista käyttämämme nimitykset olisivat todennäköisesti aivan toisenlaiset kuin ne nyt ovat.

Siihen nähden, kuinka paljon työtä ja vaivaa suomen sijamuotojen nimitykset ovat aiheuttaneet S2- ja äidinkielen opetuksessa, niitä on tutkittu hämmästyttävän vähän. Yksi harvoista, joka on aiheesta tarkemmin kirjoittanut, on Kalevi Wiik (1988). Hän toteaa Virittäjässä ilmestyneen artikkelinsa lopuksi, ikään kuin anteeksi pyydellen:

Tiedän, että monen lukijan mielestä olen tarttunut kovin pinnalliseen aiheeseen, nominien sijojen nimiin. Myönnän, että aihe on pinnallinen. Pinnallisuutta olen edellä koettanut hälventää pohtimalla sijoja hiukan muiltakin kannoilta [---] (Wiik 1988: 467.)

Wiikin artikkelin ilmestymisen aikoihin kielioppitermistöä ei ehkä pidetty kyllin painavana tutkimusaiheena. Nykyisin termistön tutkimukseen kuitenkin rohkaistaan. "Tieteen kansallisen termipankin" johtaja Tiina Onikki-Rantajääskö (esim. Onikki-Rantajääskö \& Jaakkola 2010: 479-480) nimittää termistöä usein tieteen infrastuktuuriksi. 
Hänen mukaansa tieteen kieli on samanlainen perusedellytys tieteelliselle toiminnalle kuin vesihuolto, sähköverkko tai tieverkosto ovat koko yhteiskunnalle. Toimiva infrastruktuuri edellyttää kehittämistä ja kunnossapitoa, mikä puolestaan edellyttää tutkimustyötä.

Termistön ja metakielen roolista vieraiden kielten oppimisessa on kirjoittanut mm. Mary Schleppegrell (esim. 2012), jonka mukaan opetuksen metakieli voi kasvattaa opiskelijoiden kielitietoisuutta ja edistää sekä sisältöjen oppimista että kielellisistä tehtävistä suoriutumista. Metakielen tulee kuitenkin olla mielekästä ja tehtäväkontekstiin sopivaa: pelkkien termien opettelemisesta on todettu olevan hyvin vähän jos ollenkaan hyötyä. Suurin hyöty metakielestä saadaan vuorovaikutuksellisessa oppimiskontekstissa, jossa käytetystä metakielestä myös keskustellaan. (Schleppegrell 2012: 153-157, 159-164.)

Kirsti Siitonen $(1999 ; 2000)$ on puolestaan tarkastellut kielioppitermistöä S2-kontekstissa ja todennut, että huonosti toimivasta metakielestä voi olla jopa haittaa: harhaanjohtava kielioppitermistö on vakava virhelähde erityisesti edistyneillä S2-opiskelijoilla. Väitöskirjassaan Siitonen (1999) on tutkinut suomen U-verbejä, joita perinteisesti on nimitetty refleksiiviverbeiksi, vaikka kaikki niistä eivät ole merkitykseltään refleksiivisiä. Nimityksen ja käytön välinen epäsuhta hämmentää opiskelijoita ja voi vaikeuttaa muutenkin työlään verbikategorian omaksumista. VIRSU-julkaisussa ilmestyneessä artikkelissaan (2000) Siitonen käsittelee kielioppitermistöä yleisesti ja haastaa kaikki S2-opetuksen parissa työskentelevät keskustelemaan ja pitämään huolta yhteisesti käytetystä kielioppitermistöstä.

Vaikka suomen kielioppitermistöstä on toistaiseksi tutkittu varsin vähän, termien merkitys opetus- ja tutkimustyössä on ymmärretty jo vanhastaan. Suomenkielisten kielioppitermien kehittämiseen rohkaisi aikoinaan $\mathrm{mm}$. Elias Lönnrot, joka totesi osuvasti:

Se vähä erehdyksen haitta, joka nimitysten muuttamisesta taitaisi tulla, kyllä pian palkitaan niiden sopivammaksi saamisella; sopiva nimi on jo puoli selitys asiasta. (Lönnrot 1847: 28.) 
Kielioppitermit ovat parhaimmillaan tiedon tiivistelmiä tai metakielellisiä ja kognitiivisia työvälineitä (Kok 2012; 2014), joiden avulla kuvataan, selitetään ja luokitellaan kielen rakenteita, prosesseja ja ilmiöitä. Muiden työvälineiden tavoin myös termistöä tulee kehittää ja huoltaa. Päivitetty ja toimiva metakieli auttaa tekemään sekä opettamisesta että opiskelusta mahdollisimman ergonomista.

Kiinnostuin termien roolista opetuksessa toden teolla, kun jouduin tekemään metakieleen liittyviä päätöksiä S2-opettajan työssäni. Opiskelijoiden terävät huomiot vaativat usein tarkistamaan toimintaani. Jouduin ottamaan kriittisen kannan siihen, kuinka opiskelijoille puhutaan kielestä ja kielellisistä ilmiöistä. Olemme esimerkiksi tottuneet käyttämään kielioppitermistöä, joka pohjautuu osittain latinaan. Unohdamme kuitenkin helposti, että osalle opiskelijoista tällainen käytäntö voi olla aivan tuntematon. Afrikkalaistaustainen opiskelija, joka kysyy opettajaltaan, mikä inessiivi on, ei välttämättä etsi tietoa inessiivin päätteestä tai siitä, kuinka inessiiviä käytetään. Hän haluaa ehkä yksinkertaisesti tietää, mikä on inessiivi-sanan merkitys. Jos opettaja ei osaa vastata opiskelijan kysymykseen, hämmästys voi olla suuri, sillä opiskelija saattaa luulla inessiivin olevan aivan tavallinen suomenkielinen sana.

Sijamuotojen nimityksistä liittyen mieleeni on jäänyt erityisesti eräs ranskalainen vaihto-opiskelija, joka osallistui suomen alkeiskurssille. Kun harjoittelimme elatiivi-sijan käyttöä - Tulen Puolasta; tulen Meksikosta; olen kotoisin Italiasta -, hän viittasi innokkaasti ja kysyi: "Is that the ablative?" Lahjakas ja tarmokas opiskelija oli etukäteen selvittänyt, että suomessa esiintyy ablatiivi-niminen sija. Hän tiesi myös, että ablatiivi-nimitys viittaa poistumiseen tai pois ottamiseen. Oli ikävä tuottaa opiskelijalle pettymys ja kertoa, että kyseistä sijaa sanotaankin elatiiviksi. Kerroin kuitenkin opiskelijalle, että hän oli aivan oikeassa: suomen $s t A$-päätteistä paikallissijaa voitaisiin kutsua ablatiiviksi aivan yhtä oikeutetusti kuin ltA-päätteistä sijaa - Tulen Venäjältä; Tulen Kyprokselta - ja näin on itse asiassa aikaisemmin tehtykin (ks. Vhael 1733; Judén 1818; von Becker 1824). 


\section{Sijamuotojen nimitykset tuotekehittelyn tuloksina: esimerkkitapauksina partitiivi ja allatiivi}

Suomen sijamuotojen nimitykset eivät ole itsestäänselvyyksiä. Partitiiviksi nimittämäämme sijaa ei ole aina sanottu partitiiviksi eikä allatiivia allatiiviksi. Itsestään selvänä ei ole aina edes pidetty, kuinka monta sijaa suomessa on tai millaisia muotoja nominien säännölliseen sijaparadigmaan kuuluu (ks. Häkkinen 2000: 171-173). Myös paikallissijojen nimitysjärjestelmä on muuttunut useaan kertaan, ennen kuin Gustaf Renvall (1840) kehitti nykyisin käytössä olevan, latinan prepositioverbeille perustuvan kuuden termin sarjan. Ainoat sijamuodot, joiden nimityksiin ei juuri ole kajottu, ovat nominatiivi ja genetiivi. Muilta osin suomen sijamuotojen nimitysjärjestelmä on pitkän tuotekehittelyn tulosta. Oppiriidoilta ja harha-askeliltakaan ei ole täysin vältytty, eikä jokainen tuotekehittelyn vaihe ole välttämättä vienyt prosessia parempaan suuntaan. Tarkastelen aluksi esimerkinomaisesti, kuinka suomen partitiivi ja allatiivi saivat nykyiset nimensä.

Suomen vanhimmat kieliopit (Petraeus 1649; Martinius 1689) nojautuivat vahvasti latinan kielioppiperinteeseen (ks. Häkkinen 2000: 173-174; Vihonen 1978), joten on melkein itsestään selvää, että partitiivin ensimmäiseksi nimeksi tuli Accusativus. Tätä nimitystä käytetään latinan kielioppiperinteessä yleisesti objektin sijasta, joten Petraeus (1649: 14-17) ja Martinius (1689: 19-27) eivät käytä nimitystä Accusativus yksinomaan partitiivista vaan muistakin objektin sijoista. Partitiiviobjektille ei siis vanhimmissa kieliopeissa ole vielä omaa nimitystä eikä partitiivia katsottu erilliseksi sijaksi. Suomen kielelle luonteenomainen ero totaali- ja osaobjektin välillä ymmärrettiin kuitenkin jo varhain. Bartholdus Vhael (1733: 12-16) käyttää partitiivista nimitystä Accusativus edeltäjiensä tapaan. Hän kuitenkin huomauttaa, että Accusativus voi esiintyä kahdessa eri asussa, jolloin sen merkityskin on erilainen:

(a) partitialem; söi leipää/comedit de pane, han åt af brödet; löi miestä/ percussit virum, slog mannen. ( $\beta$ ) Totalem: söi leivän/ totum comedit panem, åt hopp et helt bröd; (Vhael 1733: 17.) 
Termien tasolla totaali- ja partitiiviobjektin eron tekee näkyväksi Jacobus Judén (1818: 19-21). Osaobjektin sijasta hän käyttää nimitystä Accusativus partitiales ja totaaliobjektin sijoista vastaavasti Accusativus Totalis.

Uusi vaihe tuotekehittelyssä alkoi, kun nykyisin partitiivina tunnetusta sijasta alettiin käyttää nimitystä Infinitivus. Uusi nimitys perustui uuteen tietoon partitiivin käytöstä ja merkityksestä. Sitä käytti ensimmäisen kerran von Becker (1824) ja myöhemmin Gustaf Renvall (1840), joka perustelee uuden termin paremmuutta aikaisempiin nähden seuraavasti:

Beträffande ordningen emellan Finskans många Casus, har jag sökt anordna dem efter relationens inbördes frändskap. Nominat. och Infinit. hafva emellan sig samma förhållande, som Sv. definit och indefinitändelserna (bröd och brödet, kyrka och kyrkan), samt brukas begge att beteckna Verbens både Subject och Object. (Renvall 1840: 51.)

Renvallin mukaan infinitivuksen ja nominatiivin välinen suhde on sama kuin ruotsin nominien epämääräiseen ja määräisen muodon suhde, esim. bröd : brödet tai kyrka : kyrkan. Nominatiivin ja infinitivuksen suhde on sama riippumatta siitä, käytetäänkö näitä kahta sijaa subjektina vai objektina. Perustelua pidettiin ilmeisen hyvänä, sillä infinitivus-nimityksestä tuli pian suosittu. Sen omaksuivat mm. Lönnrot (1841/1842), Finelius (1845), Eurén (1846; 1849; 1851), Collan (1847), Corander (1861) ja Gottlund (1863).

Myös suomenkielisiä nimityksiä partitiiville kehiteltiin. Lönnrotin (1836: 44) partitiivista käyttämä nimitys kohdinta perustuu selvästi akkusatiiviin käsitteelle ja viittaa partitiivin käyttöön objektin sijana, kun taas Eurénin (1852) käyttämä osanto viitannee spesifimmin osaobjektiin eli "osannaiseen kohtaloon":

Tästä näkyy, että kohtalo taitaa suomessa olla joko täysinäinen eli osannainen; edellinen seisoo joko nimennössä eli yksikön omannossa, jälkimäinen aina osannossa. Niin on kohtalo hewonen osannainen tässä: saatiin hewosta eli hewosia metsään, mutta täysinäinen tässä: saatiin hewosen eli hewoset metsään. (Eurén 1852: 128-129.) 
Partitiivi- ja totaaliobjektin ero ymmärrettiin siis hyvin jo Vhaelista (1733) alkaen, ja ero tuotiin myöhemmin esille sekä latinan- että suomenkielisessä termistössä. Akkusatiivin käsitteeseen perustuvien termien rinnalla käytettiin nimitystä infinitivus, joka viittaa partitiivisijan epämääräisyyttä ilmaisevaan merkitykseen.

Terminä partitiivi (tai partitivus) otettiin käyttöön 1860-luvulla, eikä sitä aluksi käytetty yksinomaan sijamuodon vaan myös ilmaisutyypin nimityksenä. Sijamuodon nimityksenä Partitivus esiintyy ensimmäisen kerran jo Koskisen (1860: 1) lauseopissa "Finska Språkets Satslära":

1. Subjektens kasus är antigen Nominativus eller Partitivus i hvardera numerus. Nominativus uttrycker subjected i dess helhet (Totalt Subjekt). Partitivus uttrycker subjektet såsom endast delvist (Partitielt Subjekt). (Koskinen 1860: 1.)

Vuotta myöhemmin ilmestyneessä lauseopissaan Corander (1861: 10-12) nimittää kuitenkin partitiiveiksi erilaisia osamäärän ilmauksia:

Mått, kardinaltalen utom yksi, komparativer, superlativer, pari och ord, som bemärk qvantitet eller mängd, kallas partitiver. (Corander 1861: 10.)

Osassa hänen esimerkeistään esiintyykin partitiivimuotoinen nomini, esim. kolme hevosta, syli puita. Osa Coranderin "partitiiveista" ei taas sisällä partitiivia lainkaan, esim. veljeksistä vanhin tai vanhempi veljeksistä. Tietynlaiset "partitiivit" kuten lukusanat vaativat Coranderin (1861: 11) mukaan kuitenkin infinitivus-sijaisen täydennyksen, josta käytetään myös nimitystä Infinitivus partitivus:

Med undantag af komparativerna fordra alla dessa partitiva, då de stå i Nominativ (äro subject, pred. eller object I satsen), det ord, hvaraf partitivet utgör en del, i Infinitivus partitivus; kardinaltalet alltid infinit. sing, de öfriga infinit. sing. eller pluralis, allt eftersom meningen fördrar, t. ex. Kolme hevosta tre hästar, sata miestä 400 karlar, syli puita on siellä, der finns en famn ved, osti nuoraa sylen köpte en famn rep, hän on veljeksiä vanhin han är äldst bland bröder. (Corander 1860: 11.) 
1860-luvun kuluessa partitiivi sijamuodon nimityksenä selkeytyi ja vakiintui. Sitä käyttivät suomen kielen oppikirjoissaan mm. Ahlmann (1864: 29) ja Kockström (1868: 101). Myös infinitivus-nimitykselle löytyi vielä kannatusta (esim. Gottlund 1863: 130), kunnes kyseistä termiä alettiin käyttää verbien infinitiivimuotojen kuvauksessa (esim Kockström 1868: 115). Judénin (1818: 26-29) Accusativus partitiales ja Eurénin (1852: 41-43) osanto ovat mahdollisesti toimineet mallina partitivinimitykselle. Tätä on kuitenkin vaikea suoraan teosten pohjalta osoittaa, sillä kaikki kielioppien tekijät eivät ole dokumentoineet ja perustelleet termivalintojaan yhtä perusteellisesti kuin esimerkiksi Renvall (1840).

Myös allatiivina tuntemaamme paikallissijaa on aikaisemmin nimitetty toisin termein. Allatiivin tuotekehittelyprosessi ei tosin ole yhtä pitkä ja monivaiheinen kuin partitivin. Noin 180 vuoden ajan allatiivia nimitettiin datiiviksi - tavalla tai toisella. Nimitystä Dativus käyttivät mm. Petraeus (1649), Martinius (1689), Vhael (1733) ja Judén (1818). ${ }^{1}$ Reinhold von Becker (1824: 23-25), joka halusi tehdä eron sisäisen ja ulkoisen "datiivin" välillä, tarkensi allatiivin nimityksen asuun Dativus exterior, kun taas sisätulosijasta eli illatiivista hän käytti nimitystä Dativus interior:

7) Dativus exterior, såsom emottagande något åt, på, till sig, t. ex. linnullen (åt fogeln), jaloillen (på fötterna), vei kirkollen (förde till kyrkan);

8) Dativus interior, såsom emottagande något in uti sig, t. ex. luoti sattui lintuun (kulan träffade uti fogeln), meni kirkkoon (geck i kyrkan); (von Becker 1824:24.)

\footnotetext{
Nimitys on latinan kielioppiperinteen mukainen. Latinan datiivi-sija on nimetty perustehtävänsä mukaan: se toimii usein antaa-verbin täydennyksenä (datum est 'annettiin, on annettu') ja vastaanottajan koodaajana samoin kuin suomen allatiivi. Latinan datiivilla on kuitenkin myös muunlaista kuten possessiivista ja finaalista käyttöä (Linkomies 1967: 61-64; Pekkanen 1988: 111-112). Latinan datiivin ja suomen allatiivin käyttöalat eivät täysin kata toisiaan. Yhteisiä piirteitä on kuitenkin niin paljon, ettei saman nimityksen käyttäminen ole keinotekoista tai mielivaltaista. (Ks. myös Miestamo 2013: 28.) 
Dativus exterior (nyk. allatiivi) ilmaisee siis von Beckerin mukaan vastaanottajan roolia yleisesti (“åt, på, till sig”), kun taas Dativus interior (nyk. illatiivi) ilmaisee, että vastaanottaminen tapahtuu vartalosanan tarkoitteen sisäpuolelle ("in uti sig"). Nimityksen Allativ tai Allativus otti käyttöön Gustaf Renvall (1840: 49-53), joka samalla luopui kokonaan datiivi-nimityksen käytöstä suomen kielen kuvauksessa. ${ }^{2}$ Renvallin luoma uusi nimitys levisi nopeasti 1800-luvun kielioppeihin (Lönnrot 1841/1842: 30; Koranteri 1845: 19; Finelius 1845: 13-17; Eurén 1846: 19-27, 1849: 37-38, 1851: 17-24; Collan 1847: 61-63; Corander 1861), ja varteenotettavia vaihtoehtoja sille olivat vain suomenkieliset nimitykset kuten tulenta (Lönnrot 1836: 44; Koranteri 1845: 20) tai annanto (Eurén 1852: 40-43).

\section{Gustaf Renvall ja paikallissijojen nimitykset}

Gustaf Renvallin (1840) kielioppi on sijamuotojen nimitysjärjestelmän kehityksen kannalta aivan keskeinen teos. Kaikkien sijojen nimitykset eivät tässä teoksessa ole vielä samat kuin ne, joita nykyisin käytetään. Erityisesti paikallissijojen nykyisistä nimityksistä voimme kuitenkin kiittää - tai syyttää - nimenomaan Renvallia.

Renvallin ehdotus suomen sijamuotojen uudeksi nimitysjärjestelmäksi on todennäköisesti pitkän harkinnan ja monien kokeilujen tulos. Renvall (1815-1818) tarkastelee suomen nominien taivutusta ja sijajärjestelmää myös 8-osaisessa väitöskirjassaan "De signis relationum nominalium in lingua fennica". Väitöskirjassa käytetyt sijamuotojen nimitykset eivät kuitenkaan ole samat kuin ne, joihin Renvall myöhemmin päätyy.

Renvallin (1840) kielioppi poikkeaa edeltäjistään erityisesti siinä, että kieliopillisia kategorioita ei tyydytä pelkästään nimeämään tai kuvaamaan esimerkkien avulla. Teoksen luku suomen sijamuodoista ja niiden nimityksistä (“Om nominers Casus", Renvall 1840:49-53) tarjoaa

2 Allativus esiintyy yläkäsitteenä jo Renvallin (1815-1818: 11) väitöskirjassa: illatiivista käytetään nimitystä allativus interior ja allatiivista allativus exterior. 
lukijalle kiinnostavan näkymän Renvallin kieliopilliseen ja teoreettiseen ajatteluun. Lisäksi luku on historiallinen katsaus sijamuotojärjestelmän kuvauksen aikaisempiin vaiheisiin. Renvall muun muassa vertailee käyttämiään nimityksiä aikaisemmin käytössä olleisiin termeihin ja laatii jopa taulukkomaisen esityksen, josta käy ilmi, kuinka hänen omat terminsä vastaavat Vhaelin ja von Beckerin käyttämiä nimityksiä: "Se här en parallele emellan mina Casus benämningar, samt Vhaels och von Beckers" (Renvall 1840: 52). Kyseinen esitys löytyy sellaisenaan asetelmasta 1. Sijojen nimitykset ovat Renvallin esittämässä järjestyksessä ja asussa, aina välimerkkejä myöten. Renvallin asetelman rinnalle olen liittänyt sijojen tavallisimmin käytetyt nykyiset nimitykset.

Asetelma 1. Renvallin (1840: 52) vertaileva esitys Renvallin omista ("Mina Casus") sekä Vhaelin (1733) ja von Beckerin (1824) käyttämistä sijamuotojen nimityksistä, joiden rinnalla nykyisin käytössä olevat nimitykset (esim. Setälä \& Sadeniemi 1975: 65)

\begin{tabular}{|c|c|c|c|}
\hline \multicolumn{3}{|c|}{ Renvall 1840: 52} & \multirow{2}{*}{$\begin{array}{c}\text { Nykyiset } \\
\text { nimitykset } \\
\text { (esim. Setälä \& } \\
\text { Sadeniemi 1975) } \\
\end{array}$} \\
\hline Mina Casus & Vhaels & v. Beckers & \\
\hline 1. Nominativ. & Nominativ. & Nominativ. & Nominatiivi \\
\hline 2. Infinit. & Accusativ. & Infinitiv. & Partitiivi \\
\hline 3. Genitiv. & Genitiv. & Genitiv. & Genetiivi \\
\hline 4. Essiv. & Nuncupativ. & Locativ. formalis. & Essiivi \\
\hline 5. Factiv. & Factiv. & Dativ. formalis. & Translatiivi \\
\hline 6. Allativ. & Dativ. & Dativ. exterior. & Allatiivi \\
\hline 7. Illativ. & Penetrativ. & Dativ. interior. & Illatiivi \\
\hline 8. Ablativ. & Privativ. & Ablativ. exterior. & Ablatiivi \\
\hline 9. Elativ. & Ablativ. & Ablativ. interior. & Elatiivi \\
\hline 10. Adessiv. & Mediativ. & Locativ. exterior. & Adessiivi \\
\hline 11. Inessiv. & Locativ. & Locativ. interior. & Inessiivi \\
\hline 12. Abessiv 1. Caritiv. & Negativ. & Caritiv. & Abessiivi \\
\hline 13. Suffixiv & & & Komitatiivi \\
\hline 14. Adverbial & Descr & & Instruktiivi \\
\hline
\end{tabular}


Asetelmasta 1 käy ilmi, että paikallissijojen nimistä allativ, illativ, elativ, adessiv ja inessiv ovat todennäköisesti Renvallin kehittämiä. Niitä ei ole käytetty aikaisemmissa kieliopeissa, eikä niille ole valmista mallia latinan tai minkään muunkaan kielen kuvauksessa. ${ }^{3}$ Renvall myös sanoo niitä omikseen ("Mina Casus"). Asetelmasta käy edelleen ilmi, että essiivi- ja abessiivi-sijojen nykyiset nimitykset ovat niin ikään peräisin Renvallilta. Translatiivista Renvall käyttää kuitenkin nimitystä Factiv(us) - samoin kuin Vhael - ja kuvailee, kuinka se muodostaa merkitysparin essiiville: "Essiv säger hurudant tinget är, varar, och Factiv, hurudant det blir, varder." (Renvall 1840: 51.)

Nimityksestä $\operatorname{ablativ(us)~tulee~panna~merkille,~että~sitä~on~käytetty~jo~}$ vanhimmissa, latinan malliin perustuvissa suomen kieliopeissa, joissa sen merkitysala on kuitenkin huomattavan laaja (ks. Vihonen 1978: 89-91; Häkkinen 2000: 173). Myöhemmissä kieliopeissa ablatiivin viittausala muuttuu. Vhaelin (1733: 15-17) ja Judénin (1818: 19-21) kuvauksissa ablativus viittaa nykyisin elatiivina tuntemaamme sijaan, kun taas von Becker käyttää ablatiivia yläkäsitteenä: sisäerosijasta hän käyttää nimitystä Ablativus interior ja ulkoerosijasta Ablativus exterior. Vasta Renvall varaa ablatiivi-nimityksen yksinomaan ulkoiselle erosijalle.

Muita suomen sijajärjestelmän kuvaukseen liittyviä uudistuksia ovat mm. komitatiivin ja instruktiivin erottaminen selkeästi kahdeksi eri sijaksi. Renvall pitää komitatiivia eräänlaisena essiivinä ja käyttää siitä nimitystä Suffixiv, koska sen kanssa käytetään aina omistusliitettä. Instruktiivista käyttämäänsä nimitystä Adverbial Renvall perustelee kyseisen sijan adverbiaalisella käytöllä. (Renvall 1840: 52, 69.) Aikaisemmissa kuvauksissa näiden kahden sijan välille ei ole tehty selvää

Renvall on mitä ilmeisimmin käyttänyt uusia paikallissijojen nimityksiään jo ennen kielioppinsa (1840) julkaisemista. Osa niistä esiintyy nimittäin Gabriel Reinin (1829) oppihistoriallisessa ja vertailevassa tutkielmassa "De declinationibus fennicis brevis expositio" (ks. Häkkinen 2000: 177; 2008: 74). Rein ei esittele termejä ominaan (vrt. Wiik 1988: 456), vaan esimerkiksi adessiivista (Mediativus) hän toteaa: "Renvall primo Locativum exteriorem, deinde Adessivum, von Becker itidem Locativum exteriorem eundem apellavit” (Rein 1829: 25-26). Väitöskirjassaan Renvall (1815-1818/1: 9-13 ) käyttää erilaista sijamuotojen nimitysjärjestelmää kuin myöhemmin kieliopissaan (1840). 
eroa, ja von Beckerin (1824: 24) esimerkki Instructivus-sijasta olisi nykykäsityksen mukaan komitatiivi: "mehtä lintuinensa (skogen med sina foglar)". Vhaelin (1733: 14-17) esimerkit ovat taas instruktiiveja (caloin, warcain, leiwin), ja Vhael käyttää kyseisestä sijamuodosta nimitystä Instructivus vel Descriptivus eikä pelkästään Descriptivus, kuten Renvallin (1840: 52) esitys antaa ymmärtää. Instruktiivi-nimitystä voidaankin pitää Vhaelin kehittämänä.

Renvall perustelee seikkaperäisesti, miksi sijamuotojen nimityksiä pitäisi muuttaa ja miksi hänen tapansa hahmottaa suomen sijajärjestelmä on parempi kuin aikaisemmat kuvaukset. Hänen mukaansa sijan käsitteellä tulisi suomea kuvatessa viitata nimenomaan pääteainekseen eikä sijan syntaktiseen tehtävään, kuten latinan kielen kuvauksissa on ollut tapana tehdä: "För mig är Casus och Nominal-ändelse synonymt" (Renvall 1840: 49). Koska suomen nomineilla on 14 erilaista päätettä, pitäisi sijojakin siis olla 14. Vanhimpia kielioppeja (Petraeus 1649; Martinius 1689) Renvall arvostelee aluksi lyhyesti siitä, että sijoja on niissä liian vähän:

Våra äldsta Grammatister ville i Finskan hafva lika många Casus, som i Latinen, och de måste derföre under Ablativen sammanpara 5 à 6 olika ändelser. (Renvall 1840: 49)

Erityisesti ablatiiville on Renvallin mukaan tehty aikaisemmissa kieliopeissa "vääryyttä", koska sen alle on sovitettu datiivia (nykyisin allatiivia) lukuun ottamatta kaikki paikallissijat (ks. esim. Petraeus 1649: 12-17; Martinius 1689: 22-23; Vihonen 1978: 82-93). Renvall on kuitenkin kritiikissään herrasmiesmäinen, eikä hän moiti vanhimpia suomen sijajärjestelmän kuvauksia yhtä ankarin sanoin kuin myöhemmin esimerkiksi Ahlqvist (1855: 6). ${ }^{4}$ Renvall vertaa omaa termijärjestelmäänsä

4 Tarkoitukseni ei millään muotoa ole ehdottaa paluuta Petraeuksen ja Martiniuksen järjestelmään. Useampien paikallissijojen nimittäminen yhteisesti ablatiiviksi ei kuitenkaan ole niin mielivaltaista tai "kelvotonta" (ks. Ahlqvist 1855: 6) kuin helposti ajatellaan. Nimitys ablatiivi viittaa pois viemiseen tai ottamiseen (lat. ablatum 'pois kannettu'), joten sen alle sopivat luontevasti suomen molemmat erosijat (elatiivi ja ablativi). Lisäksi latinan ablatiivi on historiallisesti kolmen sijan yhteensulautuma, 
edelleen Judénin (1818) kielioppiin, jossa sijoja on hänen mukaansa aivan liian monta (Renvall 1840: 50). Asetelmassa 2 on esitetty Judénin käyttämät sijamuotojen nimitykset esimerkkeineen sekä niitä vastaavat nykyiset nimitykset. Tummennuksella on havainnollistettu, että Renvallin kritiikki kohdistuu erityisesti adessiivi-sijan nimityksiin.

Asetelma 2. Suomen sijamuodot Judénin (1818: 20-21) kieliopissa sekä niitä vastaavat nykyiset nimitykset. Nykyistä adessiivia vastaavat nimitykset on esitetty tummennettuna

\begin{tabular}{|l|l|l|}
\hline Exempel till CASUS (Judén 1818: 20-21) & Nykyiset nimitykset \\
\hline Nominativus & tuoli on matala & nominatiivi \\
\hline Genetivus & tuolin jalka & genetiivi \\
\hline Dativus & tuolille panna & allatiivi \\
\hline Accus. Partitialis & tuolia tehdä & partitiivi \\
\hline Accus. Totalis & tuolin särkeä & genetiivi(n kaltainen akkusatiivi) \\
\hline Vocativus & Ah! tuoli raukka & - \\
\hline Ablativus & tuolista puhua & elatiivi \\
\hline Locat. Inesse & tuolissa on vika & inessiivi \\
\hline Locat. Supresse & tuolilla istua & adessiivi \\
\hline Possessivus & tuolilla on neljä jalkaa & adessiivi \\
\hline Mediativus & tuolilla lyödä & adessiivi \\
\hline Privativus & tuolilda ottaa & ablatiivi \\
\hline Negativus & tuolita olla & abessiivi \\
\hline Mutativus & tuoliksi tehdä & translatiivi \\
\hline Nuncupativus & tuolina pitää & essiivi \\
\hline Penetrativus & tuoliin hakata & illatiivi \\
\hline Descriptivus & $\begin{array}{l}\text { tuolin (kirvein) päälle } \\
\text { käydä. }\end{array}$ & instruktiivi \\
\hline
\end{tabular}

jolla erosijaisen merkityksensä (ablativus separativus) lisäksi on mm. lokatiivisia ja instrumentaalisia merkityksiä. Latinan ablatiivi on myös yleinen prepositiosija ja monenlaisten adverbiaalien sija. (Ks. Linkomies 1967: 63-70; Pekkanen 1988: 112120). Useat sen eri käyttötavoista on mahdollista rinnastaa suomen paikallissijojen käyttötapoihin. Vihosen (1978: 90-93) mukaan erityisesti Martinius (1689: 90-91) on hyvin oivaltanut suomen paikallissijojen päätteiden ja latinan prepositioiden keskinäiset vastaavuudet. 
Asetelmasta 2 käy ilmi, että ulkoisella olosijalla eli adessiivilla on Judénin järjestelmässä kolme erilaista nimitystä. Tämä on Renvallin mukaan tarpeetonta:

af tuolilla har Herr Judén gjort 3 särskilta Casus, då han dock bort säga, att denna enda Casus utrycker tre olika relationer (Renvall 1840: 50).

Judénin adessiivista käyttämät nimitykset Locativus Supresse, Possessivus ja Mediativus viittaavat erilaisiin semanttisiin suhteisiin, joita $l l A$-päätteen avulla ilmaistaan. Renvallin mukaan Judénin olisi ollut parempi puhua yhdestä sijasta ja sen ilmaisemasta kolmesta merkityssuhteesta kuin hahmottaa kaikki merkityssuhteet erillisiksi sijoiksi. Renvall lienee oikeassa: Judénin esitys (1818: 20-21) on ihailtavan perusteellinen mutta ei pidemmän päälle kovin ergonominen (ks. Kok 2012; 2014). Adessiivin lisäksi muillakin sijoilla - tai niiden pääteaineksella - on enemmän kuin yksi ainoa merkitys tai tehtävä. Sijajärjestelmän kuvaus paisuisi tarpeettoman raskaaksi, jos jokaisen sijapäätteen kaikki tehtävät pitäisi hahmottaa erillisiksi sijamerkiksi. Judénin termejä voisi kuitenkin soveltaen hyödyntää alemman käsitetason termeinä ja puhua esim. ulkopaikan adessiivista, omistajan adessiivista tai välineen adessiivista.

Renvall (1840: 49-50) siis määrittelee sijan puhtaasti morfologiseksi kategoriaksi (vrt. edellä "För mig är Casus och Nominal-ändelse synonymt"), ja ainakin suomen kielen kuvauksessa lienee järkevintä menetellä edelleen samalla tavoin. Hänen järjestelmässään on 14 sijaa, jotka on nimetty päätehtävänsä mukaan. Renvall on tosin tietoinen siitä, että yksi ja sama sija voi ilmaista useita kieliopillisia suhteita. Renvall (1840: 50) antaakin Vhaelille (1733) tunnustusta siitä, että sijoja ja niiden nimityksiä on hänen kieliopissaan oikea määrä. Jostain syystä Renvall ei kuitenkaan innostu Vhaelin nimityksistä vaan päätyy luomaan oman termijärjestelmänsä.

Erityisesti paikallissijojen uusi nimitysjärjestelmä on perusteellinen irtiotto latinan kielioppien mallista ja aikaisemmasta kuvausperinteestä, vaikka itse termit pohjautuvatkin latinan prepositioalkuisiin yhdysverbeihin. Renvall käyttää olosijojen nimitysten perusosana latinan 
olla-verbiä ja nimenomaan sen infinitiivimuotoa esse, johon on liittynyt sisä- ja ulkosijan eroa ilmaiseva prepositio: inessiv(us) on sisäolosijan nimitys ja adessiv(us) vastaavasti ulko-olosijan nimitys. Myös nimitykset essiv(us) ja abessiv(us) pohjautuvat latinan olla-verbiin. Tulo- ja erosijojen nimitykset on puolestaan johdettu verbimuodosta latum, joka on epäsäännöllisen fero-verbin ('kantaa, viedä, tuoda') partisiippimuoto (esim. latum est 'kannettiin, on kannettu'). Partisiippijohdannaiseen on edelleen liitetty sopiva prepositio osoittamaan tulo- ja erosijaisuutta sekä sisä- ja ulkosijaisuutta. Tulosijojen nimityksissä illativ(us) ja allativ(us) esiintyvät prepositiot in sekä ad assimiloituneessa asussa osoittamassa sisä- ja ulkosijan eroa. Erosijojen nimityksissä elatiivi ja ablatiivi esiintyvät vastaavasti prepositiot $e(x)$ ja $a b$. Huomattakoon, etteivät paikallissijojen uudet nimitykset ole keinotekoisia preposition ja verbimuodosteen yhdistelmiä, vaan ne pohjautuvat todella olemassa oleviin verbeihin (ks. esim. Linkomies 1967: 115). Koska latina kuului 1800-luvun kouluaineisiin, myös Renvallin oppilaat todennäköisesti tunsivat tällaisia verbejä. Niiden pohjalta laadittu termijärjestelmä on hyvinkin voinut olla heille varsin havainnollinen, "jo puoli selitys asiasta" (vrt. edellä Lönnrot 1847: 28).

Renvallin kehittämät paikallissijojen nimitykset omaksuttiin aluksi innolla ruotsinkielisiin suomen kielioppeihin (esim. Finelius 1845: 13-20; Eurén 1846: 20-30; Collan 1847: 47-65; Eurén 1849: 37-54; Gottlund 1863: 130; Jahnsson 1871: 43-75; Salonius 1885: 24-28). Myös eräissä suomenkielisissä teoksissa niitä käytettiin rinnakkaisnimityksinä (esim. Koranteri 1845: 19), vaikka aluksi suomenkielisissä kieliopeissa ja oppikirjoissa suosittiinkin suomenkielisiä termejä (esim. Eurén 1852; Länkelä 1867; Ronkainen 1881: 8-10). Setälän (1880: 6-26; 1898: 44-47) ja Genetzin (1881: 22-23; Jännes 1895: 45-48) teoksissa Renvallin termien äänne- ja kirjoitusasu suomalaistettiin, ja vähitellen ne vakiintuivat pääasiallisiksi termeiksi myös moniin suomenkielisiin kielioppeihin (esim. Hämäläinen 1883: 23-50; Mietintö 1888: 30; Kallio 1890: 16-25). 


\section{Onko Renvallia nyt kiittäminen vai syyttäminen?}

On aiheellista kysyä, tekikö Gustaf Renvall palveluksen vai karhunpalveluksen suomen kielen kuvaukselle ja ennen kaikkea suomen kielen opiskelijoille. Miten onnistuneina tuotteina hänen termejään voidaan pitää? Niissä on paljon hyvää, ja varsinkin latinantaitoisia nimitykset ovat todennäköisesti aikanaan auttaneet ymmärtämään suomen paikallissijajärjestelmää paremmin. Nimitykset kuvaavat kohteitaan varsin hyvin eivätkä missään tapauksessa ole samalla tavoin harhaanjohtavia kuin esimerkiksi suomen aikamuotojen nimitykset imperfekti ja perfekti (ks. Siitonen 2000; Kok 2012; 2014). Termien rakenne on läpinäkyvä, ja yhdessä ne muodostavat loogisen järjestelmän, joka lisäksi on innovatiivinen ja omaperäinen: siitä huolimatta, että termit ovat latinaa, ne eivät pohjaudu latinan tai minkään muunkaan vieraan kielen kuvausmalliin, vaan ne on tehty mittatilaustyönä suomen kielen kuvausta varten.

Renvallin kehittämät paikallissijojen nimitykset ovat kuitenkin aiheuttaneet paljon ongelmia sekä S2- että äidinkielen opetuksessa. Pahin ongelma lienee, että ne jäävät vieraiksi niille, jotka eivät osaa latinaa tai jotka eivät varta vasten näe suurta vaivaa niiden alkuperän ja merkityksen selvittämiseksi. Latinaan pohjautuvia kielioppitermejä on suomessa toki muitakin, mutta Renvallin kehittämiä paikallissijojen nimityksiä ei juuri käytetä muiden kielten kuvauksessa, joten useimmille opiskelijoille niissä ei ole mitään tuttua. Opiskelijoiden on vaikea oppia muistamaan, mikä nimitys viittaa mihinkin sijaan. Opettajillekaan muistaminen ei aina ole helppoa, sillä harvat suomen kielen opettajat osaavat nykyään latinaa eikä termejä tai niiden merkityksiä välttämättä selitetä missään opettajankoulutuksen vaiheessa. Muutenkin tieto vaikuttaa olevan kiven alla: Alhon \& Kauppisen (2004: 47) "Käyttökielioppi" on yksi harvoista teoksista, jossa sijamuotojen nimien merkitystä avataan.

On muitakin seikkoja, jotka rajoittavat Renvallin paikallissijojen nimitysten käyttökelpoisuutta opiskelun välineinä. Nurinkurista on, että nämä termit tuottavat toisinaan päänvaivaa nimenomaan niille opiskelijoille, joilla olisi parhaat edellytykset hyödyntää niitä. Ensinnäkin 
ablatiivi-termin viittausala on Renvallin järjestelmässä huomattavasti kaventunut aikaisempiin kuvauksiin verrattuna. Tämä voi olla hämmentävää sellaiselle opiskelijalle, joka tuntee ablatiivi-termin entuudestaan tai tietää, että se viittaa pois viemiseen (ablatum 'pois kannettu'). Opettajan olisi hyvä osata selittää, että ablatiivin paikka käsitehierarkiassa on historian saatossa muuttunut. Latinan kuvausperinteessä ablatiivi on jo nimestäkin päätellen erosija, vaikka sillä on myös muita tehtäviä (Pekkanen 1988: 112-120). Von Beckerin (1824) kuvauksessa Ablativus taas on yläkäsite, jonka alle kuuluvat sekä suomen sisäinen että ulkoinen erosija. Renvallin järjestelmässä ablativ(us) viittaa yksinomaan ulkoiseen erosijaan.

Miksi Renvall sitten katsoi tarpeelliseksi irrottautua aikaisemmasta kuvausperinteestä ja muuttaa ablatiivin viittausalaa? Mahdollisesti hän piti uutta elatiiv(us)-termiään erityisen hyvänä nimityksenä sisäerosijalle, mitä se kieltämättä onkin (elatum 'ulos kannettu'). Vanhempi ja merkitykseltään yleisluontoisempi $\operatorname{ablatiiv(us)-termi~sai~näin~ollen~jäädä~}$ ulkoerosijan nimeksi. Tähänkin tehtävään se soveltuu hyvin.

Toiseksi Renvall on kokonaan hävittänyt datiivi-nimityksen suomen sijamuotojen kuvausjärjestelmästä ja samalla häivyttänyt taka-alalle datiivin käsitteen. Tätä on vaikea perustella millään kielitieteellisellä tai merkitykseen liittyvällä syyllä. Latinan datiivin perusmerkitys on jokseenkin sama kuin suomen allatiivin: se ilmaisee vastaanottajan tai ns. epäsuoran objektin tarkoitteen. Tämän lisäksi latinan datiivilla on muutakin käyttöä, myös sellaista, jota suomen allatiivilla ei ole. (Pekkanen 1988: 109-112.) On siis totta, etteivät suomen allatiivin ja latinan datiivin käyttöalat täsmälleen kata toisiaan, mutta samaa voidaan sanoa myös muista kielistä, joiden järjestelmään kuuluu datiivi: sen päämerkitys on vastaanottajan koodaaminen, minkä lisäksi muitakin kielispesifejä tehtäviä voi olla. Nimityksestä datiivi voisivat hyötyä esimerkiksi opiskelijat, joiden äidinkielessä tai joiden tuntemassa muussa kielessä esiintyy datiivi-niminen sija.

Miten Renvall sitten perustelee irtiottoaan aikaisemmasta kuvausperinteestä? Miksi hän katsoi aiheelliseksi luopua datiivi-nimityksestä 
ja kaventaa ablatiivi-termin viittausalaa? Renvallin oman selonteon mukaan kyse on paitsi selkeydestä myös tyyliseikoista:

"Skillnaden emellan det yttre och inre förhållandet kunde väl ock uttryckas med orden exterior och interior, såsom Herr von Becker gjort, men en Casus benämning, bestående av två särskilta ord, synes mig besvärlig och släpande [---]" (Renvall 1840: 52.)

Hän ei siis moiti datiivin käsitettä sinällään sopimattomaksi suomen kielen kuvaukseen. Hän ei myöskään väitä, että nimityksellä ablatiivi voitaisiin viitata vain ulkoiseen erosijaan. Jokaiselle paikallissijalle - tai päätteelle - tarvitaan hänen mukaansa kuitenkin oma nimi, josta tulee käydä ilmi, onko kyseessä sisä- vai ulkosija ja olo-, ero- vai tulosija. Von Beckerin käyttämät nimitykset kuten locativus interior, locativus exterior, dativus exterior tai ablativus interior täyttäisivät periaatteessa nämä vaatimukset, mutta Renvall pitää ongelmana niiden moniosaisuutta: kahdesta erillisestä sanasta koostuvat termit ovat kömpelöitä ja hankalia ("besvärlig och släpande"), vaikka niiden avulla itse asia saataisiin ilmaistua oikein. (Renvall 1840: 52.) Ilmeisesti Renvallille ei riittänyt, että termit olivat sisällöllisesti oikeat. Hän halusi myös, että niiden ulkoasu olisi mahdollisimman onnistunut. ${ }^{5}$

Mitä kannattaisi nyt tehdä, jotta Renvallin kehittämistä paikallissijojen nimityksistä olisi käyttäjäkunnalle mahdollisimman paljon hyötyä ja mahdollisimman vähän haittaa? On monia syitä sille, ettei näitä nimityksiä tulisi heittää muitta mutkitta yli laidan. Ne ovat ensinnäkin yksiselitteiset: samalla nimityksellä viitataan aina samaan sijaan tai samaan pääteainekseen. Sisällöllisesti termit ovat myös varsin onnistuneet, vieläpä tyylikkäät. Lisäksi ne ovat hyvin vakiintuneet suomen kielen kuvauksiin ja oppikirjoihin. Myös kansainvälisessä tutkimuskirjallisuudessa

5 Von Beckerin kaksiosaiset termit eivät itse asiassa ole kömpelöitä. Ne vain noudattavat latinassa ja muissakin romaanisissa kielissä tavallista sanajärjestystä, jonka mukaan kuvaileva adjektiivi, kuten internus tai externus esiintyy pääsanansa (locativus, dativus, ablativus) jäljessä. Mahdollisesti Renvall piti latinan sanajärjestystä ruotsinkielisessä tekstissä häiritsevänä. 
niitä käytetään nykyään yleisesti. Monia käyttäjäryhmiä ne palvelevat siis hyvin. Renvallin termien hyvät puolet pääsisivät kuitenkin paremmin oikeuksiinsa, jos niistä myös tiedettäisiin ja puhuttaisiin enemmän. Esimerkiksi suomen kieltä yliopistossa opiskeleville, lukiolaisille tai edistyneille S2-opiskelijoille voisi aivan hyvin selittää, mistä nämä termit ovat peräisin, mitä ne merkitsevät ja miten ne on rakennettu. Olenkin omassa opetuksessani ottanut tavakseni menetellä juuri näin, jos katson opiskelijoiden hyötyvän tästä. Yliopiston, lukion tai edistyneiden S2-opiskelijoiden kurssilla vie noin puoli tuntia selittää ryhmälle, mitä merkitsevät olosijat eli "essiivit", suuntasijat eli "latiivit" sekä prepositiot in, $a d, e(x)$ ja $a b$. Tämä ei edellytä opiskelijoilta latinan tuntemusta, sillä kyseisillä prepositioilla on tunnistettavia vastineita opiskelijoiden osaamissa kielissä kuten englannissa ja saksassa. Myös latinan olla-verbi ja epäsäännöllinen kantaa-verbi esiintyvät monissa sivistyssanoissa (esim. ablaatio 'poistoleikkaus') sekä englanninkielisissä sanoissa (esim. translation 'käännös'; essential 'olennainen'). Opettaja voi auttaa opiskelijoita näkemään yhteyden tällaisten sanojen ja Renvallin kielioppitermien välillä.

\section{Vaihtoehtoista tuotekehittelyä perus- ja S2-opetuksen tarpeisiin}

Perusasteen äidinkielen opetuksessa sekä A-B-taitotason S2-opetuksessa kaivattaisiin kuitenkin rinnakkaistermejä tai vaihtoehtoisia nimityksiä suomen paikallissijoille. Periaatteessa sellaisia olisikin jo tarjolla, mutta ehkä vanhat tottumukset ja oppimateriaalien käytänteet estävät hyödyntämästä niitä optimaalisesti. Mitäpä jos leikkisimme hetken ajatuksella, että Renvall ei olisikaan uudistanut paikallissijojen nimitysjärjestelmää! Millainen termistö meillä olisi nyt käytössä? Mahdollisesti se perustuisi tavalla tai toisella von Beckerin (1824) "kömpelöihin ja hankaliin” moniosaisiin termeihin. Ehkä ne olisivat käytössä sellaisenaan, tai kenties niitä olisi käännetty suomeksi tai muille kielille, joko kokonaan tai osittain. Ehkä niiden äänneasua olisi suomalaistettu tai niille 
olisi keksitty kokonaan suomenkieliset vastineet. Asetelmassa 3 olen esittänyt, millaisia nimityksiä von Becker (1824: 23-24) paikallissijoista käyttää ja millaisia termejä niiden pohjalta voitaisiin rakentaa, jos ne suomennettaisiin osittain. Mukana asetelmassa ovat myös yleiset paikallissijat essiivi ja translatiivi sekä niiden nimitykset. Suomentamani nimitykset eivät käsittääkseni ole aikaisemmin olleet käytössä, joten rohkenen esittää ne omina ehdotuksinani. Mahdotonta ei tietenkään ole, että joku muu olisi päätynyt samanlaisiin käännöksiin ja käyttänytkin niitä.

Asetelma 3. Von Beckerin (1824) käyttämät paikallissijojen nimitykset, mukaan lukien essiivi ja translatiivi, sekä ehdotuksia niiden suomenkielisiksi vastineiksi

\begin{tabular}{|l|l|}
\hline \multicolumn{1}{|c|}{ von Becker (1824: 23-24) } & \multicolumn{1}{c|}{$\begin{array}{c}\text { Omia ehdotuksia } \\
\text { suomenkielisiksi vastineiksi }\end{array}$} \\
\hline Locativus interior: kalassa & sisälokatiivi \\
\hline Locativus exterior: kalalla & ulkolokatiivi \\
\hline Locativus formalis: kalana & $\begin{array}{l}\text { olotilan lokatiivi } \sim \text { totaalilokatiivi } ~ \\
\text { kokonaislokatiivi }\end{array}$ \\
\hline Ablativus interior (et formalis): kalasta & sisäablatiivi \\
\hline Ablativus exterior: kalalta & ulkoablatiivi \\
\hline Dativus interior: kalaan & sisädatiivi \\
\hline Dativus exterior: kalalle & ulkodatiivi \\
\hline Dativus formalis: kalaksi & $\begin{array}{l}\text { olotilan datiivi } \sim \text { totaalidatiivi } ~ \\
\text { kokonaisdatiivi }\end{array}$ \\
\hline
\end{tabular}

Asetelmasta 3 käy ilmi, että von Becker (1824) hahmottaa suomen kielestä kolme erilaista lokatiivia eli olosijaa (Locativus), kaksi ablatiivia eli erosijaa (Ablativus) ja kolme erilaista datiivia eli tulosijaa (Dativus). Sisäja ulkosijojen välistä eroa osoittavat adjektiivit interior ja exterior, kun taas adjektiivi formalis viittaa muotoon, hahmoon tai olotilaan. Ehdotan von Beckerin termien suomenkielisiksi vastineiksi nimityksiä, joiden 
perusosa on säilytetty mutta mukautettu suomeen (lokatiivi, ablatiivi ja datiivi). Sisä- ja ulkosijojen välistä eroa osoittavat adjektiivit (interior, exterior) on taas suomennettu kokonaan (sisä-, ulko-). Termien rakennetta on myös muokattu suomen kieleen sopivammaksi. Latinalle tyypilliset sanaliittotermit on muutettu määritysyhdyssanoiksi, ja näin on päästy eroon Renvallin vieroksumista kaksiosaisista nimityksistä. Von Beckerin termijärjestelmä olisi yksinkertaista kääntää myös englanniksi, esim. inner locative, outer dative tai inner ablative. Saman logiikan mukaan termit voitaisiin haluttaessa kääntää muillekin suomen opetuksen apukielille.

Von Becker (1824) hahmottaa myös essiivin eräänlaiseksi lokatiiviksi (Locativus formalis "olla muodoltaan jotain") ja translatiivin eräänlaiseksi datiiviksi (Dativus formalis "ottaa vastaan muoto tai olotila"). Vastaavasti elatiivilla voi olla paitsi sisäablatiivin myös muodon tai olotilan ablatiivin merkitys (Ablativus interior \& formalis), jolloin sillä ilmaistaan esimerkiksi muodonmuutoksen lähtöpistettä:

Locativus formalis, såsom hafvande den begreppet tillhöriga skepnad (forma) eller beskaffenhet, t. ex. lintuna (såsom fogel), vaelsi sairaana (reste såsom sjuk); (von Becker 1824: 25).

Dativus formalis, såsom emottagande en skepnad (forma) eller beskaffenhet, t. ex. muиttuu linnuksi (förvandlas till fogel), vesi kylmettyy jääksi (vattnet frös till is); (von Becker 1824: 24).

linnusta munttui kalaksi (förvandlades af fogel till fisk), lapsesta kasvoi mieheksi (växte af barn till karl. I sistnämde fall brukas denna Ablativus formaliter och svarar då emot de öfvriga Casus formales. (von Becker 1824: 25.)

Jos ajatus olotilan lokatiivista tai datiivista tuntuu väkinäiseltä, nimityksiä essiivi ja translatiivi voitaisiin hyvin käyttää jatkossakin. Erityisesti translatiivi kuuluu niihin termeihin, jotka opitaan varsin helposti, etenkin jos opiskelijat osaavat hieman englantia ja apuna voidaan käyttää esimerkiksi sellaisia tuttuja sanoja kuin transport 'kuljetus' tai translation 'käännös' 
Kaikilla suomen sijamuodoilla on jo vanhastaan ollut myös kokonaan suomenkieliset nimet. Useimmat niistä ovat alkujaan Elias Lönnrotin kehittämiä, ja edelleen niitä ovat muokanneet esimerkiksi Eurén (1852). Näitä nimityksiä käytetään nykyään harvoin, ja syynä tähän lienee ajan patina, joka tuo mukanaan häiritsevät konnotaatiot:

On tunnettua, että esimerkiksi sijannimi olento [kursivointi kirjoittajan] on kouluissa huono siitä syystä, että monet oppilaat tajuavat sanan väärin (so. merkityksessä "hahmo, olio") (Wiik 1988: 467).

Deskriptiivisissä kielenkuvauksissa (esim. Ahlqvist 1877: 86-118; ISK; Alho \& Kauppinen 2004) on kuitenkin jo pitkään käytetty olo- ero- ja tulosija-nimityksille perustuvaa termijärjestelmää, jonka kehittäjä mitä ilmeisimmin on August Ahlqvist (1877: 86-118; ks. Wiik 1988: 456457). Teoksessaan "Suomen kielen rakennus, vertaavia kieliopillisia tutkimuksia” Ahlqvist (1877: 92) johdattelee lukijan suomen paikallissijojen järjestelmään seuraavin sanoin:

Paikallisuus on kolminainen: yleinen paikallisuus, sisäinen paikallisuus ja ulkoinen paikallisuus. Edellensä on kolme eri muotoa kustakin paikallisuudessa tapahtuvasta teosta mahdollista, taikka, toisin sanoen, subjektin toimiminen paikallisuudessa voipi olla kolmea eri laatua: olo jossakin paikassa, ero jostakin paikasta, ja meno eli tulo johonkin paikkaan. Tämän mukaan voipi kielessä syntyä yhdeksän eri muotoa paikallisuutta toimittamaan ja Suomen kieli onkin näille yhdeksälle muodolle hankkinut taivutussijat. (Ahlqvist 1877: 92.)

Asetelmassa 4 on esitetty, kuinka nykyiset paikallissijojen nimitykset, Lönnrotin (1836) ja Eurénin (1852) kehittämät nimitykset sekä August Ahlqvistin suomenkieliset nimitykset vastaavat toisiaan. Asetelmassa on myös kuvattuna, kuinka Ahlqvistin kehittämiä nimityksiä hyödynnetään "Isossa suomen kieliopissa" sekä Alhon \& Kauppisen (2008) "Käyttökieliopissa”. 
Asetelma 4. Paikallissijojen nykyiset nimitykset verrattuna Lönnrotin ja Eurénin käyttämiin nimityksiin sekä Ahlqvistin (1877) kehittämiin kuvaileviin nimityksiin, joita käyttävät myös esimerkiksi ISK sekä Alho \& Kauppinen (2008)

\begin{tabular}{|c|c|c|c|c|}
\hline $\begin{array}{l}\text { Nykyiset } \\
\text { nimitykset }\end{array}$ & $\begin{array}{c}\text { Lönnrot } \\
(1836, \\
1847) \\
\end{array}$ & $\begin{array}{l}\text { Eurén } \\
(1852)\end{array}$ & $\begin{array}{c}\text { Ahlqvist } \\
\text { (1877) }\end{array}$ & $\begin{array}{c}\text { ISK; Alho \& } \\
\text { Kauppinen } \\
(2008)\end{array}$ \\
\hline essiivi & olenta & olento & $\begin{array}{l}\text { yleinen olosija (hist.); } \\
\text { maineen olosija }\end{array}$ & $\begin{array}{l}\text { yleinen / abstrakti } \\
\text { olosija }\end{array}$ \\
\hline inessiivi & asunta & asunto & sisäinen olosija & $\begin{array}{l}\text { sisäinen olosija / } \\
\text { sisäolosija }\end{array}$ \\
\hline adessiivi & pidäntä & sivunto & ulkoinen olosija & $\begin{array}{l}\text { ulkoinen olosija / } \\
\text { ulko-olosija }\end{array}$ \\
\hline (partitiivi) & & & yleinen erosija (hist.) & \\
\hline elatiivi & erintä & lähdentö & sisäinen erosija & $\begin{array}{l}\text { sisäinen erosija / } \\
\text { sisäerosija }\end{array}$ \\
\hline ablatiivi & lähdentä & otanto & ulkoinen erosija & $\begin{array}{l}\text { ulkoinen erosija / } \\
\text { ulkoerosija }\end{array}$ \\
\hline translatiivi & muutunta & muutanto & maineen tulosija & $\begin{array}{l}\text { yleinen / abstrakti } \\
\text { tulosija }\end{array}$ \\
\hline illatiivi & yhdyntä & menentö & sisäinen tulosija & $\begin{array}{l}\text { sisäinen tulosija / } \\
\text { sisätulosija }\end{array}$ \\
\hline allatiivi & tulenta & annanto & ulkoinen tulosija & $\begin{array}{l}\text { ulkoinen tulosija / } \\
\text { ulkotulosija }\end{array}$ \\
\hline
\end{tabular}

Lisäksi Ahlqvistin nimitykset ovat sävyltään neutraaleja eivätkä herätä outoja assosiaatioita kuten eräät Lönnrotin ja Eurénin käyttämät nimitykset. Jostain syystä niitä ei kuitenkaan ole nostettu varsinaisiksi termeiksi. Sekä Ahlqvist itse (1877) että myöhemmin esimerkiksi ISK ja Alho \& Kauppinen (2008) tyytyvät käyttämään nimityksiä deskriptiivisesti: niiden avulla kuvataan sijamuotojen merkityksiä ja selitetään, mitä sijojen "kieliopilliset nimet" (Ahlqvist 1877: 106) tarkoittavat:

Paikallissijoissa on mukana myös vastakohta pysyvän paikan ja paikkaan suuntautumisen välillä. Olosijat ilmentävät konkreettisessa tapauksessa pysyvää tilannetta ja suuntasijat taas muutosta. Muutos tai 
liike voi olla kahdenlaista: paikasta eroamista tai paikkaan tulemista. Puhutaankin erosijoista ja tulosijoista. Olo- ja suuntasijan ero on näkyvissä myös sijojen nimityksissä, sillä olosijassa esiintyy termi essiivi ja suuntasijoissa termi latiivi. (Alho \& Kauppinen 2008: 47.)

Näitä sijoja kutsutaan kieliopissa, olosijaa adessiiviksi, erosijaa ablatiiviksi ja tulosijaa allatiiviksi (Ahlqvist 1877: 106).

Näiden sijojen kieliopilliset nimitykset ovat: inessiivi, elatiivi ja illatiivi (Ahlqvist 1877: 106).

Huomattakoon, ettei Ahlqvistin (1877) tutkielma ole koulukielioppi vaan historiallinen esitys suomen nominien johto- ja taivutusopista. Esimerkiksi nimityksellä yleinen erosija viitataan partitiivi-sijan vanhaan merkitykseen ja käyttöön (esim. kotoa). Samoin yleinen olosija viittaa essiivi-sijan aikaisempaan käyttöön paikallissijana (esim. kotona). Essiiviä sen nykyisessä käytössään Ahlqvist (1877: 110) kuvailee maineen olosijana, ja translatiivia hän luonnehtii maineen tulosijaksi. Ahlqvistin tutkielman päätavoitteena ei ollut kehittää uutta termistöä vaan kuvata suomen sijajärjestelmän syntyä ja kehitystä. Mahdollisesti juuri tämän vuoksi Ahlqvist piti kehittämiään nimityksiä vain apukäsitteinä eikä "kieliopillisina nimityksinä", jollaisiksi ne kuitenkin hyvin soveltuisivat.

Ahlqvistin termeistä sisäistä ja ulkoista erosijaa voisi pitää von Beckerin termien Ablativus internus ja Ablativus externus sananmukaisina käännöksinä. Nimitykset olosija ja tulosija ovat vapaampia sovelluksia, joissa esiintyy piirteitä sekä von Beckerin että Renvallin termistöstä. Nimitys tulosija ei nimittäin merkitse kirjaimellisesti samaa kuin datiivi, jonka taustalla on latinan antaa-verbi (esim. datum est 'annettiin/on annettu'). Niin ikään lokatiivi ja olosija eivät ole toistensa käännösvastineita, vaikka ne viittaavatkin samaan sijamuotoryhmään. Nimitys olosija perustuu suomen olla-verbiin (vrt. essiivi < lat. esse, Renvall 1840), kun taas lokatiivi palautuu latinan paikkaa merkitsevään sanaan locus. Ahlqvist on epäilemättä tuntenut sekä von Beckerin että Renvallin termistön ja mahdollisesti myös hyödyntänyt niitä. Kuinka tietoisesti ja 
tarkoituksella tämä on tapahtunut, ei ole selvää. Termien käyttökelpoisuuteen tämä ei tietenkään vaikuta millään tavoin. Itse asiassa olosija saattaa nykykäytänteiden valossa olla jopa yksiselitteisempi termi kuin lokatiivi. Esimerkiksi Saija Merken (2012: 209-210) tarkastelema ranskalaisten S2-opiskelijoiden ryhmä käyttää paikallissijoista yleisesti nimitystä "les locatifs".

Ahlqvistin (1877) nimityksistä sisäinen ja ulkoinen olosija sekä sisäinen ja ulkoinen erosija ovat yksiselitteisiä ja myös useimmille S2-opiskelijoille helppoja hahmottaa: inessiiville ja adessiiville sekä elatiiville ja ablatiiville olisi siis jo tarjolla hyvät suomenkieliset nimitykset. Hankaluuksia voi sen sijaan tuottaa tulosija. Kielitieteilijät ja opettajat kyllä tietävät, että nimitys tulosija viittaa vartalosanan tarkoitetta kohti suuntautuvaan liikkeeseen. Opiskelijoiden mielessä tulo-määrite assosioituu kuitenkin helposti tulla-verbiin, joka täydentyy kaksisuuntaisesti. Mielleyhtymä on vieläpä suomen johto-opin valossa täysin luonteva. Ovathan tulo-substantiivi ja tulla-verbi samakantaisia. Erityisesti S2-opiskelijoita tulosija voi hämmentää ja johtaa harhaan. Toisaalta nimitys voi johdattaa ajattelemaan, että tulla-verbin kanssa käytettäisiin aina tulosijoja: tulla kotiin; tulla yliopistolle. Käytännössä opiskelijat ovat kuitenkin harjoitelleet paljon erosijojen käyttöä tulla-verbin yhteydessä: tulen Helsingistä; tulen Venäjältä. Sekaannuksen vaara kasvaa entisestään, jos opiskelijat - ja varomattomat opettajat - keksivät ottaa kuvioihin mukaan vielä mennä-verbin, joka niin ikään täydentyy kaksisuuntaisesti. ${ }^{6}$ Sellaisen käsiteparin kuin "tulo- ja menosijat" ei soisi vakiintuvan S2-suomen eikä äidinkielenopetuksen metakieleen. Mikäli tulosija-nimitystä halutaan hyödyntää, opettajien on noudatettava suurta huolellisuutta ja varauduttava käyttämään ylimääräistä aikaa siihen, etteivät tulla-verbi ja tulosija rinnastuisi harhaanjohtavalla tavalla opiskelijoiden tajunnassa.

Vielä parempi tietenkin olisi, jos opetuksen tarpeisiin löytyisi suomenkielinen nimitys, joka sopisi datiivin tai tulosijan vastineeksi ja josta kävisi yksiselitteisesti ilmi, että liike kohdistuu vartalosanan tarkoitteeseen eikä siitä pois. Aineksia tällaiseen termin kehittelyyn voisi tarjota

6 tulla- ja mennä-verbeistä S2-opetuksessa ks. esim. Määttä 2013. 
edellä mainittu Wiikin (1988) artikkeli suomen sijamuotojen nimistä. Wiik ei varsinaisesti pyri luomaan uusia termejä. Hän pitää kuitenkin Renvallin kehittämiä nimityksiä epähavainnollisina ja pohtii, millaisia elementtejä hyvässä nimityksessä pitäisi olla.

Ennen kuin suomalainen tietää, mikä sija on esimerkiksi illatiivi, hän käy mielessään luettelon inessiivi elatiivi, illatiivi, ja vasta tämän jälkeen hän tietää, että kysymyksessä on 'johonkin sisään tulemisesta (sic!)' (luettelon järjestys on olosija, erosija, tulosija). Sijanimien epähavainnollisuus saattaa perustua siihen, että niissä ei muodon (so. prefiksien ja sanojen essiivi ja latiivi) ja merkityksen välillä ole selvää vastaavuussuhdetta. (Wiik 1988: 462.)

Wiik ei artikkelissaan perehdy latinan verbien semantiikkaan, joten Renvallin termien hienot piirteet jäävät häneltä huomaamatta. Wiikin (1988: 461-466) kuvaus paikallissijojen nimien rakenteesta on hieman mekaaninen, vaikka ei sinänsä virheellinen. Nimitysten esitetään yksinkertaisesti koostuvan perusosasta (olosijoilla essiivi, suuntasijoilla latiivi) sekä sisäistä, ulkoista tms. ulottuvuutta kuvaavasta prefiksistä, kuin rakennuspalikoista ikään. ${ }^{7}$ Puukaavioiden avulla Wiik (1988: 462-468) erittelee kuitenkin varsin kiinnostavasti niitä merkityssuhteita, joita suomen paikallissijat ilmaisevat kahden nominin välillä. Analyysinsa hän tiivistää piirreasetelmaksi (asetelma 5) saatesanoin:

Teen seuraavan ajatusleikin: Kuvitellaan, että haarapuun eri oksille annetaan siinä mielessä mahdollisimman havainnolliset nimet, että jokaisesta sijanimestä ilmenevät sijan kaikki merkityspiirteet. Miltä tällaiset sijannimet näyttävät? Ainakin ne olisivat mahdollisimman kaukana sellaisista yksiosaisista nimistä kuin essiivi ja olento [kursivointi kirjoittajan]. Ne voisivat näyttää seuraavilta: (Wiik 1988: 464)

\footnotetext{
Latinan prepositioalkuiset yhdysverbit ovat merkityskokonaisuuksia ja enemmän kuin osiensa summa, esim. allatiivi < allatum 'luokse tuotu'; ablatiivi < ablatum 'pois kannettu'; elatiivi < elatum 'ulos kannettu' (ks. esim. Linkomies 1967: 115).
} 
Asetelma 5. Suomen sijamuotojen ilmaisemat merkityssuhteet kahden nominin välillä Wiikin (1988: 464) mukaan. Varsinaisten paikallissijojen lisäksi tarkasteltavina ovat essiivi, translatiivi ja abessiivi

\begin{tabular}{|c|c|c|c|c|c|}
\hline inessiivi & PAIKAN & SISÄISYYDEN & \multicolumn{2}{|c|}{ SIJAINNIN } & sija \\
\hline elatiivi & PAIKAN & SISÄISYYDEN & POIS- & SUUNNAN & sija \\
\hline illatiivi & PAIKAN & SISÄISYYDEN & KOHTI- & SUUNNAN & sija \\
\hline adessiivi & PAIKAN & ULKOISUUDEN & \multicolumn{2}{|c|}{ SIJAINNIN } & sija \\
\hline ablatiivi & PAIKAN & ULKOISUUDEN & POIS- & SUUNNAN & sija \\
\hline allatiivi & PAIKAN & ULKOISUUDEN & KOHTI- & SUUNNAN & sija \\
\hline essiivi & \multicolumn{2}{|l|}{ TILAN } & \multicolumn{2}{|c|}{ SIJAINNIN } & sija \\
\hline translatiivi & \multicolumn{2}{|l|}{ TILAN } & KOHTI- & SUUNNAN & sija \\
\hline abessiivi & \multicolumn{2}{|c|}{ OMISTUKSEN } & \multicolumn{2}{|c|}{ SIJAINNIN } & sija \\
\hline
\end{tabular}

Asetelmasta 5 käy ilmi, etteivät Wiikin hahmottamat merkityssuhteet juuri eroa niistä, joita von Becker (1824), Renvall (1840) tai Ahlqvist (1877) ovat aikaisemmin esittäneet. Toisin kuin Wiik (1988: 461-462) väittää, merkityssuhteet käyvät varsin selvästi ilmi myös aikaisemmista nimityksistä. Ei myöskään ole selvää, miksi Wiik katsoo ainoastaan abessiivin ilmaisevan habitiivista suhdetta. Onhan ulkopaikallissijojen habitiivinen käyttö erittäin yleistä (ks. esim. Vilkuna 1996: 80-81; ISK \$1247). Wiikin ajatusleikin parasta antia ovat kuitenkin suuntasijojen määritteet pois- ja kohti-. Juuri sellaisia kaivattaisiin, jotta suuntasijoille - erityisesti tulosijoille - saataisiin yksiselitteiset suomenkieliset nimitykset. Myönnettäköön, etteivät sisäinen ja ulkoinen kohtisija ole yhtä tyylikkäitä termejä kuin sisä- tai ulkotulosija. Perusasteen ja S2-opetuksen arjessa ne voisivat kuitenkin olla käyttökelpoisia metakielellisiä työvälineitä.

\section{Lopuksi}

Vanhojen kielioppien tarkastelu uusin silmin voi tuoda päivänvaloon innovaatioita, jotka jostain syystä ovat aikoinaan jääneet syrjään. Osa niistä tarjoaa aineksia uusien ja parempien terminologisten tuotteiden kehittelyyn. Ei kannata kuitenkaan katsella vain menneisyyteen. Monelle suomen kielen opetuksen parissa työskentelevälle on vuosien 
varrella kertynyt kokemusta hyvistä metakielisistä käytänteistä, joita olisi aiheellista jakaa ja jalostaa. Tarvittaisiin myös enemmän keskustelua metakielen roolista sekä opetuskäytänteiden että oppimisprosessin kannalta. On selvää, ettei kielioppitermien opettaminen tai oppiminen voi olla tavoite sinänsä, vaan metakielen tulee aina pysyä palvelijan paikalla. On myös ilmeistä, ettei kaikille opiskelijaryhmille kannata käyttää samanlaista metakieltä. Paljon riippuu siitä, millaisia tietoja ja taitoja opiskelijoiden on tarkoitus ottaa haltuun. Jos tavoitteena on harjaantua käyttämään suomen kielen rakenteita arkielämässä, metakieli voi olla huomattavasti kevyempää ja epävirallisempaa kuin silloin, kun tarkoitus on lisätä opiskelijoiden kielitietoa. Olisi kuitenkin hyvä, jos eri taitotasoilla käytettävät metakielet eivät ainakaan olisi ristiriidassa keskenään.

Opetuksessa kannattaisi tuoda rohkeammin esille myös vaihtoehtoisia termejä ja termijärjestelmiä. Näin opiskelijoiden olisi helpompi tutustua uusiin oppikirjoihin ja kielioppeihin, myös sellaisiin, joiden esitystapa poikkeaa tutusta ja turvallisesta. Opiskelijoiden tarpeet ja taitotaso tulee tietenkin ottaa huomioon. Joskus voi erikoisempi termistö tai lähestymistapa kuitenkin auttaa oivaltamaan asioita, jotka oman oppikirjan sivuilla ovat jääneet hämäriksi. Lisäksi hyvilläkin termeillä on rajoituksensa. Lönnrotin (1847: 208) jo edellä mainitun näkemyksen mukaan onnistunut nimitys on "jo puoli selitys asiasta". Tämä implikoi, että asian toinen puoli saattaa vielä kaivata selitystä. Vaihtoehtoinen termi voi valaista kohdettaan toiselta puolelta, jolloin saman asian erilaiset nimitykset täydentävät toisiaan. Lienee jokseenkin hedelmätöntä pitää dativiva ja allatiivia toistensa kilpailijoina ja kiistellä siitä, kumpi nimitys sopii paremmin kuvaamaan suomen ulkoisen tulosijan käyttöä. Opiskelijalle voi olla hyötyä kummankin nimityksen tuntemisesta, sillä perinteinen datiivi kuvaa hyvin lle-sijan habitiivista käyttöä, kun taas allatiivi (< lat. allatum, 'luokse tuotu', ks. esim. Linkomies 1967: 115) kertoo enemmän kyseisen sijan paikallisesta käytöstä. Samoin eri termijärjestelmätkin voivat täydentää toistensa aukkoja. Renvallin kehittämä paikallissijojen nimitysjärjestelmä ei välttämättä ole parempi - eikä myöskään huonompi - kuin von Beckerin (1824) termijärjestelmä tai 
Ahlqvistin (1877) kuvaileva suomenkielinen järjestelmä. Kaikissa niissä on vahvuutensa. Kukin niistä valottaa suomen paikallissijojen käyttöä hieman eri näkökulmasta.

\section{Aineisto}

Ahlman, Ferdinand 1864. Lärokurs i Finska Språket för skolornas lägre klasser II. G. W. Helsingfors: Edlunds förlag. [SWK 6: 25.]

Ahlqvist, August 1877. Suomen kielen rakennus. Vertaavia tutkimuksia I. Nominien Synty ja Taivutus. Suomalainen Runo-oppi. Helsinki: Suomalaisen Kirjallisuuden Seura. [SWK 7: 30.]

von Becker, Reinhold 1824. Finsk Grammatik. Åbo: Bibel-sällskapets tryckeri. [SWK 2: 6.]

Collan, Fabian 1847. Finsk språklära. Förra delen, formläran. Helsingfors: J. C. Frenckell \& Son. [SWK 4: 17.]

Eurén, Gustaf 1846. Grunddragen till Finsk Formlära. Åbo: J. C. Frenckell \& Son. [SWK 4: 16.]

Euren, Gustaf 1849. Finsk språklära. Åbo: J. C. Frenckell \& Son. [SWK 4: 18.]

Euren, Gustaf 1851. Finsk språklära i sammandrag. Åbo: J. W. Lillja \& Co. [SWK 5: 19.]

Euren, Gustaf 1852. Suomalainen kielioppi suomalaisille. Turku: J. W. Lillja \& Co. [SWK 5: 20.]

Finelius, Karl 1845. Finsk språklära för lägre elementar-skolor. Wasa: Wollfska Boktryckeriet. [SWK 4: 15.]

Genetz, Arvid 1881. Suomen kielen äänne- ja muoto-oppi ynnä runous-oppi: Oppikouluja varten. Helsinki: K. E. Holm. [SWK 8: 30.]

Hämäläinen, Konstantin 1883. Suomenkielen muoto-oppi. Helsinki: K. Hämäläinen. [SWK 8: 33.]

Jahnsson, Adolf Waldemar 1871. Finska språkets satslära: För läroverkens behof. Helsingfors: Utgifvarens förlag. [SWK 7: 29.]

Judén, Jacobus 1818. Försök till utredande af finska språkets grammatik. Wiborg: And. Cederwaller. [SWK 2: 5.]

Jännes [Genetz], Arvi 1895. Suomen kielioppi: Alkeis-, muoto- ja runo-oppi oppikouluja varten. Helsinki: Weilin \& Göös. [SWK 10: 42.]

Kallio, Aukusti Herman 1890. Suomen kielioppi ensimmäistä alkeisopetusta varten. Helsinki: Suomalaisen Kirjallisuuden Seura. [SWK 10: 39.] 
Kockström, Victor Reinhold 1868. Lärobok i finska språket: Första läseårets wårtermins kurs. Helsingfors: Finska Litteratur-sällskapets tryckeri, författarens förlag. [SWK 7: 28.]

Kockström, Victor Reinhold 1872. Lärobok i finska språket: Tredje delen. Helsingfors: Finska Litteratur-sällskapets tryckeri, G. W. Edlunds förlag. [SWK 7: 28.]

Koranteri [Corander], Henrik Konstantin 1845. Suomalainen kieli-oppi, koulujen tarpe'eksi: Ruotsalaisen esi-puheen kanssa opettajalle. 1. Wiipuri: Johanna Cederwaller \& Son. [SWK 4: 14.]

Koskinen, Yrjö 1860. Finska språkets satslära: Ett försök. Åbo: J. W. Lilja. [SWK 5: 22.]

Länkelä, Jaakko 1867. Suomen kielen kielioppi. Helsinki: Weilin ja Göös. [SWK 6: 26.]

Lönnrot, Elias 1836 [1991]. Suomen kielestä. Mehiläinen 3/1836. - Elias Lönnrot, Mehiläinen. Valitut teokset 2. Toim. Raija Majamaa. SKS:n toimituksia 531. Helsinki: Suomalaisen Kirjallisuuden Seura, 42-46.

Lönnrot, Elias 1841/1842 [1991]. Bidrag till Finska språkets grammatik. Suomi 1842/1842, s. 11-47. - Elias Lönnrot, Kirjoitelmia ja lausumia. Valitut teokset 3. Toim. Raija Majamaa. SKS:n toimituksia 551. Helsinki: Suomalaisen Kirjallisuuden Seura, 118-147. [SWK 3: 11.]

Lönnrot, Elias 1847 [1991]. Grammatikaliska termer på Finska. Litteraturblad för allmän medborgerlig bildning 9/1847, s. 266-268. - Elias Lönnrot, Kirjoitelmia ja lausumia. Valitut teokset 3. Toim. Raija Majamaa. SKS:n toimituksia 551. Helsinki: Suomalaisen Kirjallisuuden Seura, 205-208.

Martinius, Matthias Martini 1698. Hodegus finnicus, eller finsk wägwijsare. - Vanhat kielioppimme: Petraeus 1649 : Martinius 1689 : Vhael 1733. Näköispainos. Helsinki: Suomalaisen Kirjallisuuden Seura, 1968. [SWK 1: 2.]

Mietintö 1888 = Mietintö kieliopillisten koulu-oppikirjojen yhtämukaisiksi järjestämisestä ynnä suomenkielisille kouluille aijottujen kielioppien luonnoksia 1888. Komiteanmietintö 1888:2. Helsinki: Keisarillinen Senaatti. [SWK 9: 37.]

Petraeus, Eskil 1649. Linguae finnicae brevis institutio. - Vanhat kielioppimme: Petraeus 1649 : Martinius 1689 : Vhael 1733. Näköispainos. Helsinki: Suomalaisen Kirjallisuuden Seura, 1968. [SWK 1: 1.]

Rein, Gabriel 2019. De declinationibus fennicis brevis expositio. Helsingforsiae: Ex Officina Typographica Frenckeliana. [SWK 2: 7.]

Renvall, Gustaf 1815-1818. De signis relationum nominalium in lingua fennica, osat 1-8. Aboae: typis Frenckellianis. https://www.doria.fi/ 
handle/10024/50699/browse?type=author\&value=Renvall\%2C+Gustaf (24.9.2018).

Renvall, Gustaf 1840. Finsk språklära: Enligt den rena vestfinska, i bokspråk vanliga dialecten. Förra delen, finska språkets formlära. Åbo: Christ. Ludv. Hjelt. [SWK 3: 10.]

Ronkainen, H. 1881. Suomalaisen kansakoulun kielioppi. Jyväskylä: Weilin \& Göös. [SWK 8: 31.]

Salonius, Paavo 1885. Praktisk läröbok i finska språket. Åbo: G. W. Wilen. [SWK 9: 35.]

Setälä, Emil Nestor 1880. Suomen kielen lauseoppi: Oppikirjan koe. Helsinki: K. E. Holm. [SWK 8: 29.]

Setälä, Emil Nestor 1892. Finska språkets satslära till läroverkens tjenst. Helsingfors: Söderström \& Co. [SWK 10: 40.]

Setälä, Emil Nestor 1898. Suomen kielioppi: Äänne- ja sanaoppi: Oppikoulua ja omin päin opiskelua varten. Helsinki: Otava. [SWK 10: 43.]

Strahlmann [Strålman], Johann 1816. Finnische sprachlehre fur finnen und nichtfinnen. St. Petersburg: M. C. Iversen. [SWK 1:4.]

SWK 1-10 = Wiik, Kalevi 1987. SWK, eli suomen wanhat kieliopit. Niteet 1-10, osat 1-43. Turku: Turun yliopiston fonetiikan laitos.

Vhael, Bartholdus Gabrielis 1733. Grammatica fennica. - Vanhat kielioppimme: Petraeus 1649 : Martinius 1689 : Vhael 1733. Näköispainos. Helsinki: Suomalaisen Kirjallisuuden Seura, 1968. [SWK 1:3.]

\section{Lähteet}

Ahlqvist, August 1855. Wiron nykyisemmästä kirjallisuudesta ['Contemporary Estonian literature']. Suomi. Helsinki: Suomal. Kirjall. Seura. http://kaino. kotus.fi/korpus/1800/meta/ahlqvist/vironkirj1855_rdf.xml (24.9.2018).

Alho, Irja, Anneli Kauppinen 2008. Käyttökielioppi ['Applied Finnish grammar']. SKS:n toimituksia 1154. Helsinki: Suomalaisen Kirjallisuuden Seura.

Häkkinen, Kaisa 2000. Suomen kirjakielen sijajärjestelmän vakiintuminen 1800-luvulla ['The stabilization of Finnish case system in standard language in the nineteenth century']. - Matti Punttila, Raimo Jussila, Helena Suni (Toim.), Pipliakielestä kirjakieleksi. Kotimaisten kielten tutkimuskeskuksen julkaisuja 105. Helsinki: Kotimaisten kielten tutkimuskeskus, 171-201.

Häkkinen, Kaisa 2008. Suomen kielen historia ['The history of Finnish']. 2, Suomen kielen tutkimuksen historia. Turun yliopiston suomalaisen ja yleisen kielitieteen julkaisuja 78. Turku: Turun yliopisto. 
ISK = Iso suomen kielioppi ['Comprehensive grammar of Finnish’]. Auli Hakulinen (päätoim.), Maria Vilkuna, Riitta Korhonen, Vesa Koivisto, TarjaRiitta Heinonen, Irja Alho. SKS:n toimituksia 950. Helsinki: Suomalaisen Kirjallisuuden Seura.

Kok, Maria 2012. Terminologia työvälineenä - aikamuotojärjestelmästä ja sen opetuskäytänteiden ergonomiasta S2-opetuksessa ['Grammatical terminology as a tool: on the tense system and the ergonomics of its teaching practices in L2-Finnish']. - Lähivertailuja 22, 101-130. https://doi.org/10.5128/ LV22.04

Kok, Maria 2014. Borrowing metalanguage: Finnish past tense terminology in grammar descriptions and teaching. - Heli Paulasto, Helka Riionheimo, Lea Meriläinen, Maria Kok (Eds.), Language Contacts at the Crossroads of Disciplines. Cambridge: Cambridge Scholars Publishing, 247-396.

Linkomies, Edvin 1967. Latinan kielioppi ['A Latin grammar']. 15. painos. Jyväskylä: Gummerus.

Merke, Saija 2012. Kielen opiskelu ja tunteet. Affekti jäsentämässä opiskelijoiden aloittamia kysymyssekvenssejä vieraan kielen oppitunneilla ['Language study and emotion: affect-driven student-initiated question sequences in foreign language classes']. - Virittäjä 116 (2), 198-230.

Miestamo, Matti 2013. Kielten vertailu kielitypologisessa tutkimuksessa ['Language comparison in language-typological research']. - Leena Kolehmainen, Matti Miestamo, Taru Norlund (Toim.), Kielten vertailun metodiikkaa. SKS:n toimituksia 1387. Helsinki: Suomalaisen Kirjallisuuden Seura, 27-55.

Määttä, Tuija 2013. Verbien tulla ja mennä rektioista ruotsinkielisten alkeistason suomenoppijoiden kirjallisissa tuotoksissa ['Government of the verbs tulla 'come' and mennä 'go' in the students' writings']. - AFinLA-e: Soveltavan kielitieteen tutkimuksia 5, 123-141. https://journal.fi/afinla/article/ view/8743 (24.9.2018).

Onikki-Rantajääskö, Tiina, Minna Jaakola 2010. Suunvuoro. - Virittäjä 114 (3), 479-480.

Pekkanen, Tuomo 1988. Ars grammatica: Latinan kielioppi ['Latin grammar']. 3. painos. Helsinki: Yliopistopaino.

Schleppegrell, Mary 2013. The role of metalanguage in supporting academic language development. - Language Learning 63 (s1), 153-170. https://doi. org/10.1111/j.1467-9922.2012.00742.x

Setälä, Emil Nestor, Matti Sadeniemi 1975. Suomen kielioppi ['Finnish grammar']. Ä̈nne- ja sanaoppi. 20. painos. Helsinki: Otava. 
Siitonen, Kirsti 1999. Agenttia etsimässä: U-verbijohdokset edistyneen suomenoppijan ongelmana [In search of an agent']. Turun yliopiston suomalaisen ja yleisen kielitieteen laitoksen julkaisuja 63. Turku: Turun yliopisto.

Siitonen, Kirsti 2000. Kieliopin terminologia tuottamassa ongelmia suomi toisena kielenä -opetuksessa. - Pirkko Muikku-Werner, Hannu Remes (Toim.). VIRSU. Viro ja suomi: kohdekielet kontrastissa. Joensuu: Joensuun yliopisto, 81-87.

Tieteen termipankki. Bank of Finnish Terminology in Arts and Scienses. http:// tieteentermipankki.fi/wiki/Termipankki:Etusivu (31.3.2018).

Vihonen, Sakari 1978. Suomen kielen oppikirja 1600-luvulla: Kieliopillinen ajattelu 1600-luvun suomen kielen oppikirjoissa ['Textbook of Finnish in the 17th century: grammatical thinking in the 1600's Finnish language textbooks. Studia philologica Jyväskyläensia 11. Jyväskylä: Jyväskylän yliopisto.

Wiik, Kalevi 1988. Suomen sijojen nimistä ['On the cases and their names in old Finnish grammars']. - Virittäjä 92, 453-468. 


\title{
On the naming system of the Finnish nominal cases: Concept analysis and product development in the 19th century Finnish grammars
}

\author{
MARIA KOK \\ University of Eastern Finland
}

This study discusses the naming system for the Finnish nominal cases as a terminological product and the research material is a collection of 17th-19th century grammars of the Finnish language. According to the findings, it can safely be concluded that most of our terms for the Finnish nominal cases originate from the 19th century. The term systems used to describe the Finnish nominal cases changed many times before the current terminology was accepted as official. The development process that leads to the terminology we have now has been long but cannot be called gradual. On the contrary, most changes in the terminological system were abrupt and may be considered conscious choices of individual scholars. Special attention in this study is given to the term system used to denote the six Finnish local cases: inessive, elative, illative, adessive, ablative and allative. This system is currently applied in most reference grammars and standard works for studying L1 and L2 Finnish and it can rightfully be attributed to Gustav Renvall (1840). Not only was this system used for the first time by Renvall, but in his grammar "Finsk Språklära Enligt den rena VestFinska" Renvall also takes credit for the new terms and gives a lengthy account of their structure and meaning. Renvall also argues why his terms should be used instead of those suggested by i.e. Vhael (1733) and von Becker (1824).

From a conceptual analytical point of view, Renvall's terms pass scrutiny on many levels. The terms are by no means incorrect or misleading. Each of them gives valid information about the meaning and use of the respective case. They also are innovative and original: only "ablative" has been used in previous grammars. The other five terms are all new and tailor-made in order to describe the core meanings of the Finnish local cases. In the language learning context, however, Renvall's terms appear to be problematic. They are based on 
ON THE NAMING SYSTEM OF THE FINNISH NOMINAL CASES

Latin prepositional verbs, which may have been a helpful feature during Renvall's lifetime but has become a disadvantage in modern-day classroom usage. Especially in L1 and L2 Finnish on the elementary level, there is a need for alternative or parallel terminology that is not only accurate but also user-friendly. A good starting point for further development might be to utilize the term system of Reinhold von Becker which is not without merits, although it was set aside shortly after Renvall's grammar appeared. Practical experience of all who teach Finnish on any educational level will probably be of great value as well.

Keywords: L2 Finnish learning; L1 Finnish learning; case system of Finnish; Finnish local cases; grammatical terminology; history of grammar tradition

\section{Maria Kok}

Itä-Suomen yliopisto, Joensuun kampus

PL 111, Yliopistokatu 2

80101 Joensuu, Finland

maria.kok@uef.fi 